\title{
Physicochemical and sensory traits of meat from Santa Inês lambs slaughtered with different subcutaneous fat thicknesses
}

\section{Ana Carla Santana Andrade1, Gladston Rafael de Arruda Santos ${ }^{2}$, Francisco de Assis Fonseca de Macedo ${ }^{2,3}$, Natália Holtz Alves Pedroso Mora ${ }^{3}$, Rosa Maria Gomes de Macedo ${ }^{4}$, Maryane Gluck Torres ${ }^{5}$}

\footnotetext{
${ }^{1}$ Universidade Federal de Sergipe, Programa de Pós-graduação em Zootecnia, Aracaju, SE, Brasil.

${ }^{2}$ Universidade Federal de Sergipe, Departamento de Zootecnia, Aracaju, SE, Brasil.

${ }^{3}$ Universidade Estadual de Maringá, Programa de Pós-graduação em Zootecnia, Maringá, PR, Brasil.

${ }^{4}$ Universidade Estadual de Maringá, Departamento de Ciências Morfológicas, Maringá, PR, Brasil.

${ }^{5}$ Universidade Estadual de Maringá, Graduação em Zootecnia, Maringá, PR, Brasil.
}

\begin{abstract}
Physical ( $\mathrm{pH}$, color, tenderness, and cooking weight loss), chemical (moisture, crude protein, ash, and lipids) and sensory (odor, flavor, juiciness, and overall acceptance) characteristics of meat from Santa Inês lambs slaughtered with 2.0, 3.0, and $4.0 \mathrm{~mm}$ of subcutaneous fat thickness (SFT) were evaluated. Samples of the longissimus dorsi muscles were removed from 24 male uncastrated lambs distributed in a completely randomized design with three treatments and eight replicates. Weightings and ultrasound evaluations were performed every 14 days. No significant differences were observed for $\mathrm{pH}_{0 \mathrm{~h}}$, which averaged 6.24. Lambs slaughtered with $4.0 \mathrm{~mm}$ SFT differed from the treatments with 2.0 and $3.0 \mathrm{~mm}$ as to the $\mathrm{pH}_{24 \mathrm{~h}}$ values. The meat from lambs slaughtered with 3.0 and $4.0 \mathrm{~mm}$ SFT showed a greater lightness ( $\mathrm{L}^{*}$ ) value. Meat tenderness $\left(2.21 \mathrm{kgf} / \mathrm{cm}^{2}\right)$, cooking weight loss $(13.90 \%)$, moisture $(74.39 \%)$, and crude protein $(22.10 \%)$ contents were not affected by the SFT. For the total lipid contents of the meat, significant differences were observed between the lambs slaughtered with $2.0 \mathrm{~mm}$ and those with 3.0 and $4.0 \mathrm{~mm}$ SFT. The sensory traits were not affected by the SFT with which the lambs were slaughtered. Lambs slaughtered with $4.0 \mathrm{~mm}$ SFT remained 33 days longer in feedlot and showed similar live weights at slaughter to those with $3.00 \mathrm{~mm}$. It is recommended to slaughter Santa Inês lambs with a subcutaneous fat thickness of $3.00 \mathrm{~mm}$.
\end{abstract}

Key Words: animal production, feedlot, lipid, protein, sheep

\section{Introduction}

The Brazilian northeastern herd consists mostly of woolless and semi-woolless animals, and it represents an activity of great economic importance for the generation of employment in rural areas.

However, in certain sectors of this activity there is low productivity, especially related to the extensive production system and the low availability of food during most part of the year in this region. These factors compromise the regularity of availability and good quality of the produced meat, as the market has been supplied with carcasses of animals with an advanced age and with undesirable traits, hindering their consumption. Based on this premise, finishing lambs in feedlots has become a strategy to maximize the production capacity of sheep and optimize meat production, in addition to accelerating the return of

Received February 12, 2015, and accepted May 26, 2015

Corresponding author: fafmacedo@uem.br

http://dx.doi.org/10.1590/S1806-92902015000800004

Copyright $@ 2015$ Sociedade Brasileira de Zootecnia. This is an Open Access article distributed under the terms of the Creative Commons Attribution Non-Commercial License, which permits unrestricted non-commercial use, distribution, and reproduction in any medium, provided the original work is properly cited. the invested capital, which results in increased productivity and profit for the producer.

Among the woolless breeds, the Santa Inês has been pointed as promising in the production of lambs for slaughter due to its reproductive efficiency, good maternal ability, and low susceptibility to endoparasites. Therefore, evaluations should be conducted to determine the ideal moment to slaughter these sheep aiming at a final product that will satisfy the consumer.

The physicochemical traits may be indicated as important parameters to qualify the sheep meat produced and increase consumers' acceptability. Among the attributes related to the acceptability of meat, color, tenderness, and juiciness are noteworthy. In sheep meat, color is associated with the product's freshness and the animals' slaughter age; tenderness indicates the meat texture; and cooking weight loss is associated with the juiciness and yield post-preparation. For Campos (2005), the sensory analysis by consumers is a methodology utilized with different objectives, among which are the study of the product quality and the indication of factors that affect consumers' perception.

Efficient animal production systems have used the subcutaneous fat thickness, evaluated by ultrasound 
imaging, to predict the tissue composition of animals in vivo and thus indicate the moment at which the desired body composition is obtained and therefore ideal for slaughter. The different sheep breed groups may not show the same carcass weight at physiological maturation, as there are groups of early, intermediate, and late maturation. Thus, adopting the subcutaneous fat thickness as a parameter for slaughtering lambs seems to be the most appropriate strategy.

The objective of this study was to evaluate the physicochemical and sensory traits of meat from Santa Inês lambs slaughtered with different subcutaneous fat thicknesses.

\section{Material and Methods}

The experiment was conducted in Maringá, northwest of Paraná State, Brazil.

Twenty-four uncastrated Santa Inês male lambs at approximately 100 days of age and with a live weight of $22.7 \pm 3.75 \mathrm{~kg}$ were used. The animals were initially weighed and their subcutaneous fat thickness (SFT) was evaluated by ultrasound, and they were subsequently distributed into the respective treatments, defined as SFT of 2.0, 3.0, and $4.0 \mathrm{~mm}$ at the longissimus dorsi muscle, between the 12 th and 13 th ribs. The lambs were dewormed by using a vermifuge with Moxidectin as active ingredient, and went through a 15-day period of adaptation to the facility and diets.

Lambs were kept in a confinement regime (feedlot) in individual $0.75 \mathrm{~m}^{2}$ covered stalls with suspended slatted floor. Water was supplied ad libitum and they were fed a complete, pelleted diet formulated to provide a daily weight gain of $0.300 \mathrm{~kg}$, with the dry matter intake estimated at $35 \mathrm{~g} \mathrm{~kg}^{-1} \mathrm{~d}^{-1}$ of the animal's live weight (NRC, 2007). The chemical composition of the diet (Table 1) was analyzed according to the methodologies described in AOAC (2000).

The evaluations by ultrasound and weighting were performed every 14 days. To obtain the SFT, an ultrasound device (HS-1500 VET, HONDA ${ }^{\circledR}$ ) with a $50 \mathrm{~mm}$ multifrequency linear transducer at $7.5 \mathrm{MHz}$ frequency was used. To obtain the measurements, the lambs were immobilized manually and had their hair removed at the measured regions, applying mucilage for a smoother probing.

All measurements were taken by the same technician, on the left site, between the 12 th and 13 th ribs, at $4 \mathrm{~cm}$ from the spinal cord. The pressure on the probe was kept minimal to avoid compression of the fat.

After the image was captured, the SFT at that point was measured using the electronic pointer of the ultrasound.

As the lambs reached the preset SFT (2.0, 3.0, and 4.0) in the fortnightly assessments, they were slaughtered on the day after the measurements, regardless of their weight. In the last weighting, the lambs with SFT of 2.0, 3.0, and $4.0 \mathrm{~mm}$ had been confined for 44, 55, and 89 days and showed average live weights of $27.14,33.84$, and $34.85 \mathrm{~kg}$, respectively. After having been deprived of solid food for $18 \mathrm{~h}$, the animals were stunned with a $220 \mathrm{~V}$ electric shock for eight seconds. After they were bled, skinned, and eviscerated, their carcasses were transferred to a cold storage room at $4{ }^{\circ} \mathrm{C}$ for $24 \mathrm{~h}$. After this period, the carcasses were sawn lengthwise and each left half-carcass was sectioned into five commercial cuts: neck, shoulder, rib, loin, and leg (Osório and Osório, 2005).

To determine the $\mathrm{pH}$ at the longissimus dorsi muscle, two measurements were taken between the 12th and 13th ribs; the first after slaughter (initial $\mathrm{pH}$ ) and the second after $24 \mathrm{~h}$ (final pH), using a Hanna HI 996163 pH meter with a penetration electrode.

The color was evaluated in 5.0-cm-thick steaks between the 1st (L1) and 6th (L6) lumbar vertebrae. Measurements were taken with a portable colorimeter (KONICA MINOLTA CR-410) operating on the CIE ( $\left.\mathrm{L}^{*}, \mathrm{a}^{*}, \mathrm{~b}^{*}\right)$ system, in which $\mathrm{L}^{*}$ is lightness, $\mathrm{a}^{*}$ is the intensity of the red color, and $\mathrm{b}^{*}$ is the intensity of the yellow color. Three measurements were taken at three different points of the stake, and the average $\mathrm{L}^{*}, \mathrm{a}^{*}$, and $\mathrm{b}^{*}$ values were recorded.

The longissimus dorsi muscle was removed from the right side of the carcass and samples were collected

Table 1 - Composition (in $\mathrm{g} \mathrm{kg}^{-1}$ of dry matter) of ingredients and chemical composition of the diet

\begin{tabular}{|c|c|}
\hline Item & Composition $\left(\mathrm{g} \mathrm{kg}^{-1}\right)$ \\
\hline Oat hay & 100.0 \\
\hline Ground corn grain & 448.0 \\
\hline Soybean meal & 150.0 \\
\hline Soybean hulls & 150.0 \\
\hline Rice meal & 100.0 \\
\hline Powder molasses & 20.0 \\
\hline Ammonium chloride & 20.0 \\
\hline Mineral mix ${ }^{1}$ & 10.0 \\
\hline Zinc bacitracin & 02.0 \\
\hline Dry matter & 912.8 \\
\hline Crude protein & 162.4 \\
\hline Ether extract & 42.1 \\
\hline Neutral detergent fiber & 275.4 \\
\hline Acid detergent fiber & 138.6 \\
\hline Ash & 45.9 \\
\hline Calcium & 02.8 \\
\hline Phosphorus & 04.0 \\
\hline In vitro dry matter digestibility ${ }^{2}$ & 782.5 \\
\hline Total digestible nutrients ${ }^{3}$ & 781.4 \\
\hline \multicolumn{2}{|c|}{$\begin{array}{l}{ }^{1} \text { Guaranteed levels per kg: calcium } 220 \mathrm{~g} \text {, phosphorus } 130 \mathrm{~g} \text {, magnesium } 25.5 \mathrm{~g} \text {; } \\
\text { sulfur } 24 \mathrm{~g} \text {; iron } 3,000 \mathrm{mg} \text {; manganese } 1,500 \mathrm{mg} \text {; zinc } 4,000 \mathrm{mg} \text {; copper } 1,200 \mathrm{mg} \text {; } \\
\text { cobalt } 280 \mathrm{mg} \text {; iodine } 260 \mathrm{mg} \text {; selenium } 30 \mathrm{mg} \text {; fluorine } 300 \mathrm{mg} \text {. } \\
{ }^{2} \text { Methodology of Tilley and Terry (1963), adapted for the use of artificial rumen, } \\
\text { developed by Ankom }{ }^{\circledR} \text {, as described by Garman et al. }(1997) \text {. } \\
{ }^{3} \text { TDN estimated by the following equation: \% TDN }=87.84-(0.70 \times \text { ADF), } \\
\text { described by Undersander et al. (1993). }\end{array}$} \\
\hline
\end{tabular}


between the 6th and 10th thoracic vertebrae for chemical analyses (moisture, ash and proteins, performed according to methodologies of AOAC (2000)). To extract the total lipids, the extraction technique described by Folch et al. (1957) was used, with a chloroform/methanol solution $\left(2: 1 \mathrm{v} \mathrm{v}^{-1}\right)$.

Samples were collected between the 10th and 13th thoracic vertebrae, vacuum-packed, and frozen to determine the cooking weight losses (CWL) and meat tenderness. The samples were previously thawed for 24 hours under refrigeration $\left(4^{\circ} \mathrm{C}\right)$ and cut into 2.5 -cm-thick steaks and weighed. Next, samples were wrapped in foil, and steaks were grilled on a grill plate pre-heated to $170{ }^{\circ} \mathrm{C}$ until reaching $70{ }^{\circ} \mathrm{C}$ in the geometric center, which was monitored using a thermometer with a digital reader. When the controlled temperature was reached, samples were taken off the grill, dried on absorbent paper, and weighed again. The cooking weight losses were calculated as the weight difference of the samples before and after cooking, expressed as percentage.

Tenderness was evaluated by measuring the shear force, through the Warner-Bratzler Shear Force Analysis Protocol - WBSF (Wheeler, 2007), using the grilled steaks to measure the cooking weight losses. Subsequently, $1.5 \times$ $1.5 \times 1.5 \mathrm{~cm}$ rectangle-shaped cuts were made according to the muscle fiber orientation. The strength necessary to transversally cut each sample was measured with a texture meter (TAXT2; Stable Micro System, Surrey, England), equipped with a Warner-Bratzler accessory operating at $20 \mathrm{~cm} \mathrm{~s}^{-1}$. The average shear force represents the tenderness value of each steak.

The samples of the L1-L6 portion of the longissimus dorsi muscles of the lambs slaughtered with 2.0 and $4.0 \mathrm{~mm}$ SFT were vacuum-packed and stored in a freezer at $-18{ }^{\circ} \mathrm{C}$ for subsequent sensory analyses on panels of consumers from both genders. The tests were conducted with consumers in Maringá/PR, Brazil, employing the methodology recommended by Campos (2005). The meat samples were thawed for $24 \mathrm{~h}$ at $4{ }^{\circ} \mathrm{C}$. Subsequently, they were cooked on a grill plate pre-heated to $170{ }^{\circ} \mathrm{C}$ until reaching $70{ }^{\circ} \mathrm{C}$ in their geometric center, which was monitored by a thermometer equipped with a digital reader. When the preset temperature was reached, samples were taken off the grill, diced, wrapped in foil, and numbered. Each consumer was given a sample from each treatment. To remove the residual taste in between samples, the consumers were offered mineral water at room temperature and unsalted crackers. A questionnaire was answered by 80 consumers, who evaluated the following parameters $(\mathrm{P})$ : odor characteristic to the species, flavor characteristic to the species, juiciness, and overall acceptance. An 8-point hedonic scale with scores divided by low intensity (1- extremely not P; 2- very un- P; 3- moderately un- P; 4- slightly un- P) and high intensity (5- slightly $\mathrm{P}$; 6- moderately $\mathrm{P}$; 7- very $\mathrm{P}$; 8- extremely P) was adopted.

The experimental design was completely randomized, having three treatments and eight replicates per treatment. Data were subjected to analysis of variance and the means (when different) were compared by Tukey's test at 5\% significance level, on the SAS (Statistical Analysis System, version 9.1) statistical software; variables were measured by the following the model:

$$
\mathrm{Y}_{i j}=\mu+\mathrm{T}_{i}+\mathrm{e}_{i j} \text {, }
$$

in which: $\mathrm{Y}_{i j}=$ observed value of the variable studied in individual $j$ receiving treatment $i ; \mu=$ overall constant; $\mathrm{T}_{i}=$ effect of treatment $i$; and $\mathrm{e}_{i j}=$ random error associated with each observation $Y_{i j}$.

\section{Results}

The initial $\mathrm{pH}\left(\mathrm{pH}_{0 \mathrm{~h}}\right)$ of the meat from Santa Inês lambs did not show differences $(\mathrm{P}>0.05)$ among the SFT, averaging 6.24 (Table 2). For the $\mathrm{pH} 24 \mathrm{~h}$ after slaughter $\left(\mathrm{pH}_{24 \mathrm{~h}}\right)$, it was found that the lambs slaughtered with 2.0 and $3.0 \mathrm{~mm}$ SFT differed $(\mathrm{P}<0.05)$ from the lambs with $4.0 \mathrm{~mm}$ SFT.

The meat color can be measured by the objective method using a colorimeter, which determines the $\mathrm{L}^{*}$ (lightness), $\mathrm{a}^{*}$ (red intensity), and $\mathrm{b}^{*}$ (yellow intensity) components. Considering the three color components, a significant difference $(\mathrm{P}<0.05)$ was only observed for lightness $\left(\mathrm{L}^{*}\right)$. The meats from lambs slaughtered with 3.0 and $4.0 \mathrm{~mm}$ of SFT showed significantly greater lightness values than those with $2.0 \mathrm{~mm}$.

The red $\left(\mathrm{a}^{*}\right)$ and yellow $\left(\mathrm{b}^{*}\right)$ components of the meat did not differ $(\mathrm{P}>0.05)$ in relation to the SFT, with mean values of 21.75 and 5.95 , respectively.

The evaluation of tenderness, determined by the shear force, has been frequently used in meat-science research. For the meats from lambs slaughtered with 2.0,3.0, and $4.0 \mathrm{~mm}$ SFT, no significant differences were detected $(\mathrm{P}>0.05)$ for tenderness, which averaged $21.21 \mathrm{kgF}$.

No difference ( $\mathrm{P}>0.05)$ was found for cooking weight

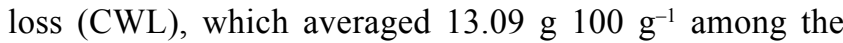
meats of the animals slaughtered with SFT of 2.0, 3.0, and $4.0 \mathrm{~mm}$.

No effect $(\mathrm{P}>0.05)$ of the different SFT was found on the moisture and protein contents, which averaged $74.39 \mathrm{~g}$

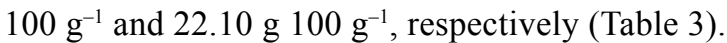

There was a difference $(\mathrm{P}<0.05)$ for the ash content of the meat, wherein the lambs from the treatment with $2 \mathrm{~mm}$ 
SFT showed a lower value than those slaughtered with $4.0 \mathrm{~mm}$ SFT.

Differences regarding total lipids were detected $(\mathrm{P}<0.05)$ among the treatments. The meats from lambs slaughtered with 3.0 and $4.0 \mathrm{~mm}$ SFT displayed the highest

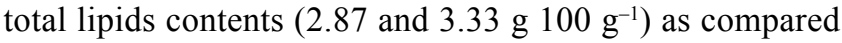

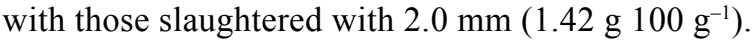

No effect of SFT was found for any of the analyzed variables in the sensory characteristics of the Santa Inês lambs' meat (Table 4).

\section{Discussion}

The values found here for $\mathrm{pH}_{0 \mathrm{~h}}$ were close to those obtained by Cunha et al. (2001) and Oliveira et al. (2004), which varied from 6.50 to 6.60 . Because it is a trait indicative of the meat quality, it is important to emphasize the detection of normal values of $\mathrm{pH}$ decline, as it can affect other characteristics such as color, tenderness, and cooking weight loss (Leão et al., 2012).

The difference found for the $\mathrm{pH}_{24 \mathrm{~h}}$ values can be attributed to the slower chilling of the carcass, as a consequence of the fat layer of lambs with $4.0 \mathrm{~mm}$, suggesting that the SFT serves as a thermal insulator (Bonagurio et al., 2003). The obtained results can be considered within the normal $\mathrm{pH}$ range for sheep meat, which is between 5.5 and 5.9 (Zapata et al., 2000; Silva Sobrinho et al., 2005). The decrease from $\mathrm{pH}_{0 \mathrm{~h}}$ to $\mathrm{pH}_{24 \mathrm{~h}}$ also behaved normally.

For meat color analysis, irrespective of the SFT with which the lambs were slaughtered, the color of the meat of the lambs from this experiment can be considered light, as their L* was between 33.40 and 37.60 , since lightness values for sheep are considered to vary from 30.03 to 49.47 (Warris et al., 2003; Leão et al., 2012).

Teixeira et al. (2005) and Martinez-Cerezo et al. (2005) found values between 11.01 and 23.04 for $\mathrm{a}^{*}$ and 4.2 and

Table 2 - Means and standard deviations for the physical characteristics of the longissimus dorsi muscle of Santa Inês lambs slaughtered with different subcutaneous fat thicknesses

\begin{tabular}{|c|c|c|c|c|}
\hline \multirow[b]{2}{*}{ Variable } & \multicolumn{3}{|c|}{ Fat thickness } & \multirow[b]{2}{*}{$\mathrm{CV}$} \\
\hline & $2.0 \mathrm{~mm}$ & $3.0 \mathrm{~mm}$ & $4.0 \mathrm{~mm}$ & \\
\hline $\mathrm{pH}_{0 \mathrm{~h}}$ & $6.33 \pm 0.18$ & $6.22 \pm 0.10$ & $6.20 \pm 0.10$ & 0.02 \\
\hline $\mathrm{pH}_{24 \mathrm{~h}}$ & $5.49 \pm 0.07 \mathrm{~b}$ & $5.50 \pm 0.10 \mathrm{~b}$ & $5.66 \pm 0.09 \mathrm{a}$ & 0.02 \\
\hline $\mathrm{L}^{* 241}$ & $33.40 \pm 0.48 b$ & $37.59 \pm 0.51 \mathrm{a}$ & $37.60 \pm 0.45 \mathrm{a}$ & 0.04 \\
\hline$a^{*}$ & $29.32 \pm 4.13$ & $18.07 \pm 4.46$ & $17.86 \pm 3.86$ & 0.50 \\
\hline$b^{*}$ & $6.03 \pm 0.17$ & $5.73 \pm 4.46$ & $6.09 \pm 0.16$ & 0.08 \\
\hline Tenderness (kgF) & $1.89 \pm 0.23$ & $2.35 \pm 0.23$ & $2.40 \pm 0.23$ & 0.30 \\
\hline Cooking weight loss $\left(\mathrm{g} 100 \mathrm{~g}^{-1}\right)$ & $12.60 \pm 1.56$ & $12.42 \pm 1.56$ & $14.26 \pm 1.56$ & 0.33 \\
\hline
\end{tabular}

Means followed by different letters differ according to Tukey's test $(\mathrm{P}<0.05)$.

$\mathrm{CV}$ - coefficient of variation; L* - lightness; $\mathrm{a}^{*}$ - red component; $\mathrm{b}^{*}$ - yellow component

Table 3 - Means and standard deviations for chemical characteristics of the longissimus dorsi muscle of Santa Inês lambs slaughtered with different subcutaneous fat thicknesses

\begin{tabular}{|c|c|c|c|c|}
\hline \multirow[b]{2}{*}{ Variable (g $100 \mathrm{~g}^{-1}$ of meat) } & \multicolumn{3}{|c|}{ Fat thickness } & \multirow[b]{2}{*}{$\mathrm{CV}$} \\
\hline & $2.0 \mathrm{~mm}$ & $3.0 \mathrm{~mm}$ & $4.0 \mathrm{~mm}$ & \\
\hline Moisture & $74.01 \pm 1.13$ & $73.55 \pm 1.13$ & $75.62 \pm 1.13$ & 0.04 \\
\hline Crude protein & $21.74 \pm 0.28$ & $22.35 \pm 0.28$ & $22.22 \pm 0.28$ & 0.04 \\
\hline Ash & $1.06 \pm 0.06 \mathrm{~b}$ & $1.12 \pm 0.06 \mathrm{ab}$ & $1.31 \pm 0.06 \mathrm{a}$ & 0.16 \\
\hline Total lipids & $1.42 \pm 0.17 b$ & $2.87 \pm 0.17 \mathrm{a}$ & $3.33 \pm 0.17 \mathrm{a}$ & 0.19 \\
\hline
\end{tabular}

Means followed by different letters in the row differ according to Tukey's test $(\mathrm{P}<0.05)$.

$\mathrm{CV}$ - coefficient of variation.

Table 4 - Means and standard deviations for sensory traits of the longissimus dorsi muscle of Santa Inês lambs slaughtered with different subcutaneous fat thicknesses

\begin{tabular}{|c|c|c|c|c|}
\hline \multirow{2}{*}{ Variable } & \multicolumn{2}{|c|}{ Fat thickness } & \multirow[b]{2}{*}{ Overall mean } & \multirow[b]{2}{*}{$\mathrm{CV}$} \\
\hline & $2.0 \mathrm{~mm}$ & $4.0 \mathrm{~mm}$ & & \\
\hline Characteristic odor & $6.39 \pm 1.78 \mathrm{a}$ & $6.84 \pm 2.18 \mathrm{a}$ & 6.25 & 0.27 \\
\hline Characteristic flavor & $6.82 \pm 1.72 \mathrm{a}$ & $7.41 \pm 1.63 a$ & 6.55 & 0.26 \\
\hline Juiciness & $6.88 \pm 1.53 \mathrm{a}$ & $7.59 \pm 1.99 \mathrm{a}$ & 6.98 & 0.22 \\
\hline Overall acceptance & $6.39 \pm 1.68 \mathrm{a}$ & $7.53 \pm 1.96 \mathrm{a}$ & 7.23 & 0.25 \\
\hline
\end{tabular}

Means followed by different letters in the row differ according to Tukey's test $(\mathrm{P}<0.05)$.

$\mathrm{CV}$ - coefficient of variation. 
9.07 for $b^{*}$. The amount of water in the meat tends to decrease with the increase in fat deposition, resulting in a lower light intensity. However, this did not occur in the current experiment. This response may be attributed mainly to the small intramuscular fat depot (marbling) in Santa Inês lambs slaughtered with 2.0 and $4.0 \mathrm{~mm}$ SFT. Santa Inês lambs slaughtered with a SFT higher than $4 \mathrm{~mm}$ must present an already significant proportion of marbling fat, sufficient to cause differences in $a^{*}$ and $b^{*}$ as compared with those slaughtered with a SFT of $2 \mathrm{~mm}$.

The meat color is related mainly to the concentration and chemical form of myoglobin, the main pigment of meat, in addition to the muscle structure and the inter- and intramuscular muscle proportion. Myoglobin is composed of globin and a prosthetic group (heme), which contains iron. The iron atom may be in ferrous $(\mathrm{Fe}++)$ or ferric $(\mathrm{Fe}+++)$ state. The iron atom from the meat hemoglobin in absence or at a low concentration of oxygen (within the cut or in the vacuum packing) is found as $\mathrm{Fe}++$, providing a dark-red meat. When the meat is exposed to an oxygen-rich environment, myoglobin is converted to oxymyoglobin, having a pink or bright-cherry color.

According to the observed results, it can be inferred that irrespective of the SFT with which the Santa Inês lambs were slaughtered, their meats could be considered tender. For Cezar and Sousa (2007), sheep meats should receive the following classifications: tender, when its shear force values are below $2.27 \mathrm{kgF}$; of medium-tenderness between 2.28 and $3.63 \mathrm{kgF}$; tough between 3.64 and $5.44 \mathrm{kgf} / \mathrm{cm}^{2}$; and extremely tough when its shear force is above $5.44 \mathrm{kgF}$.

The cooking weight loss is important in the determination of the meat quality, characterized mainly by the losses occurring during the process of preparation of the meat for consumption, which interfere with its juiciness. In the study of Vieira et al. (2010), CWL varied from 21.6 to $25.3 \mathrm{~g}$ $100 \mathrm{~g}^{-1}$ among the studied treatments. In the experiment of Pinheiro et al. (2009), however, CWL values ranged from

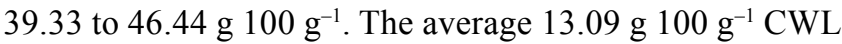
found in this experiment can be considered excellent, since lower CWL may promote greater meat juiciness.

In this study, the moisture and protein contents found in the meat from Santa Inês lambs are within the range attributed to young animals of the ovine species, which is

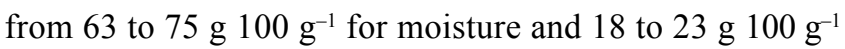
for protein (Tshabalala et al., 2003; Ortiz et al., 2005). Overall, regarding the obtained results, ash contents compatible with

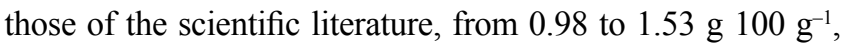
were found (Madruga et al., 2006; Freire et al., 2010).

This outcome of greater deposition of lipids in the longissimus dorsi muscle of lambs slaughtered with a SFT greater than $3 \mathrm{~mm}$ may be attributed to the longer time spent in the feedlot by these lambs in relation to those slaughtered with $2.0 \mathrm{~mm}$. It should be taken into account that the lambs belonged to the same breed group and received the same diet. The values obtained for the lipid contents corroborate Lopes et al. (2012) and Menezes Junior (2014).

Although the sensory evaluations did not differ between treatments, it is important to discuss the scores attributed by the consumers to the analyzed variables. The characteristic odor to the species received a score of 6.25 , and the characteristic flavor received an overall mean score of 6.55 , demonstrating the consumers' ability to identify sheep meat.

For juiciness, the test averaged 6.8, which is close to 7.0 , so this meat can be classified as very juicy. The overall mean of 7.23 attributed by the consumers to overall acceptance of the Santa Inês lambs' meat, regardless of the SFT with which the animals were slaughtered, allows us to state that, by the hedonic scale, their meat was classified as extremely well-accepted.

\section{Conclusions}

Lambs slaughtered with 3.0 and $4.0 \mathrm{~mm}$ SFT produce meats with superior characteristics for color and total lipids. However, the animals slaughtered with $4.0 \mathrm{~mm}$ SFT remained confined 33 days longer and showed similar live weight to those with $3.0 \mathrm{~mm}$, which shows their unfeasibility. Therefore, it is recommended to slaughter Santa Inês lambs with a subcutaneous fat thickness of $3.00 \mathrm{~mm}$.

\section{Acknowledgments}

We gratefully acknowledge the financial support granted by Conselho Nacional de Desenvolvimento Científico e Tecnológico (No. 473604/2012-4).

\section{References}

AOAC - Association of Official Analytical Chemistry. 2000. Official methods of analysis. 17th ed. AOAC International, Arlington.

Bonagurio, S.; Pérez, J. R. O.; Garcia, I. F. F.; Bressan, M. C. and Lemos, A. L. C. 2003. Qualidade da carne de cordeiros Santa Inês puros e mestiços com Texel abatidos com diferentes pesos. Revista Brasileira de Zootecnia 32:1981-1991.

Campos, M. M. 2005. Consumidores. p.409-422. In: Estandarización de las metodologias para evaluar la calidad del produto (animal vivo, canal, carne y grasa en los ruminantes). Cañeque, V. and Sañudo, C., eds. INIA, Madrid.

Cezar, M. F. and Sousa, W. H. 2007. Carcaças ovinas e caprinas: obtenção, avaliação e classificação. Editora Agropecuária Tropical, Uberaba.

Cunha, E. A.; Bueno, M. S.; Santos, L. E.; Roda, D. S. and Otzuki, P. 2001. Desempenho e características de carcaça de cordeiros 
Suffolk alimentados com diferentes volumosos. Ciência Rural 31:671-676.

Freire, M. T. A; Nakao, M. Y.; Guerra, C. C.; Carrer, C. C.; Souza, S. C. and Trindade, M. A. 2010. Determinação de parâmetros físicoquímicos e de aceitação sensorial da carne de cordeiros proveniente de diferentes tipos raciais. Alimentos e Nutrição 21:481-486.

Folch, J.; Less, M. and Sloane, S. G. H. 1957. A simple method for the isolation and purification of total lipids from animal tissues. The Journal of Biological Chemistry 226:497-509.

Garman, C. L.; Holden, L. A. and Kane, H. A. 1997. Comparison of in vitro dry matter digestibility of nine feedstuffs using three methods of analysis. Journal of Dairy Science 80(suppl.1):260.

Leão, A. G.; Silva Sobrinho, A. G.; Moreno, G. M. B.; Souza, H. B. A.; Giampietro, A.; Rossi, R. C. and Perez, H. L. 2012. Características físico-químicas e sensoriais da carne de cordeiros terminados com dietas contendo cana de açúcar ou silagem de milho e dois níveis de concentrado. Revista Brasileira de Zootecnia 41:1253-1262.

Lopes, J. E. L.; Sales, R. O.; Azevedo, A. R. and Oliveira, A. R. T. 2012. Composição centesimal, perfil de ácidos graxos e colesterol da carne de cordeiros submetidos aos sistemas de produção com dieta experimental e convencional. Revista Brasileira de Higiene e Sanidade Animal 6:31-50.

Madruga, M. S.; Araújo, W. O.; Sousa, W. H.; Cézar, M. F.; Galvão, M. S. and Cunha, M. G. G. 2006. Efeito do genótipo e do sexo sobre a composição química e o perfil de ácidos graxos da carne de cordeiros. Revista Brasileira de Zootecnia 35:1838-1844.

Martínez-Cerezo, S.; Sañudo, C. and Panea, B. 2005. Breed, slaughter weight and ageing time effects on consumer appraisal of three muscles of lamb. Meat Science 69:795-805.

Menezes Junior, E. L.; Batista, A. S. M.; Ladim, A. V.; Araujo Filho, J. T. and Holando Junior, E. V. 2014. Qualidade da carne de ovinos de diferentes raças de reprodutores terminados sob dois sistemas de produção. Revista Brasileira de Saúde e Produção Animal 15:517-527.

NRC - National Research Council. 2007. Nutrient requirements of small ruminants: sheep, goats, cervids, and new world camelids. National Academy Press, Washington, DC.

Oliveira, I.; Silva, T. J. P.; Freitas, M. Q.; Tortelly, R. and Paulino, F. O. 2004. Caracterização do processo de rigor mortis em músculos de cordeiros e carneiros da raça Santa Inês e maciez da carne. Acta Scientiae Veterinariae 32:25-31.
Ortiz, J. S.; Costa, C.; Garcia, C. A. and Silveira, L. V. A. 2005 Medidas objetivas das carcaças e composição química do lombo de cordeiros alimentados e terminados com três níveis de proteína bruta em creep feeding. Revista Brasileira de Zootecnia, $34: 2382-2389$.

Osório, J. C. S. and Osório, M. T. M. 2005. Produção de carne ovina: Técnicas de avaliação in vivo e na carcaça. 2.ed. Universidade Federal de Pelotas, Pelotas.

Pinheiro, R. S. B.; Jorge, A. M.; Mourão, R. C.; Polizel Neto, A.; Andrade, E. N. and Gomes, E. F. B. 2009. Qualidade da carne de cordeiros confinados recebendo diferentes relações de volumoso: concentrado na dieta. Food Science and Technology 29:407-411.

Silva Sobrinho, A. G.; Purchas, R. W.; Kadim, I. T. and Yamamoto, S. M. 2005. Características de qualidade da carne de ovinos de diferentes genótipos e idades ao abate. Revista Brasileira de Zootecnia 34:1070-1076.

Teixeira, A. J.; Batista, S.; Delfa, R. and Cadavez, V. 2005. Lamb meat quality of two breeds with protected origin designation. Influence of breed, sex and live weight. Meat Science 71:530-536.

Tilley, J. M. A. and Terry, R. A. 1963. A two stage technique for the "in vitro" digestion of forage crop. Journal of Britain Grassland Society 18:104-111.

Tshabalala, P. A.; Strydom, P. E.; Webb, E. C. and Kock, H. I. 2003. Meat quality of designated South African indigenous goat and sheep breeds. Meat Science 65:563-570.

Undersander, D. J.; Howard, W. T. and Shaver, R. D. 1993. Milk per acre spreadsheet for combining yield and quality into a single term. Journal of Production Agriculture 6:231-235.

Vieira, T. R. L.; Cunha, M. G. G. and Garruti, D. S. 2010. Propriedades físicas e sensoriais da carne de cordeiros Santa Inês terminados em dietas com diferentes níveis de caroço de algodão integral (Gossypium hirsutum). Ciência e Tecnologia de Alimentos 30:372-377.

Warris, P. D.; Carrascal, J. L. and López, R. C. 2003. Ciencia de la carne. Acribia, Zaragoza

Wheeler, T. L.; Schackelford, S. D. and Koohmarie, M. 2007. Beef Longissimus slice shear force measurement among steak locations and institutions. Journal Animal Science 85:2283-2289.

Zapata, J. F. F.; Seabra, L. M. J. and Nogueira, C. M. 2000. Estudo da qualidade da carne ovina no nordeste brasileiro propriedades físicas e sensoriais. Ciência e Tecnologia de Alimentos 20:274-277. 